\title{
Altitudinal zonation of mosses in west of the Sierra Nevada of Cocuy, Boyacá, Colombia
}

\author{
Alexander Mejia ${ }^{1}$, (D) Viviana Castro $^{1}$, (D) Denilson F. Peralta ${ }^{2,3}$ and (D) Bibiana Moncada ${ }^{1}$
}

Received: 10.03.2020; accepted: 18.05.2020

How to cite: Mejia, A., Castro, V., Peralta, D.F. \& Moncada, B. 2020. Altitudinal zonation of mosses in west of the Sierra Nevada of Cocuy, Boyacá, Colombia. Hoehnea 47: e162020. http://dx.doi.org/10.1590/2236-8906-16/2020.

\begin{abstract}
Altitudinal zonation of mosses in west of the Sierra Nevada of Cocuy, Boyacá, Colombia). This study was carried out with bryophyte populations in order to study the presence of populations and how they change over altitudinal gradients. Mosses were chosen as a model to do this study because they have a high sensitivity to climatic conditions and wide distribution. The western region of the Sierra Nevada del Cocuy, Boyacá, Colombia has a wide range of climate and ecosystems due to its complex topography. Plots were sampled every $200 \mathrm{~m}$ from the peak of Mount Mahoma at 4,200 m a.s.l. south to the Chicamocha River canyon at 1,200 $\mathrm{m}$ a.s.l. Diversity and cover are analyzed in each plot from soil, rock and bark substrates. We found 80 species distributed in 29 families, with Pottiaceae and Brachytheciaceae the most diverse families. Ours results show a tendency of the diversity and the coverage to increase with altitude, and we observed five altitudinal belts with three populations defined by mosses species. The Páramo and Superpáramo belts are the richest ones. Keywords: altitudinal gradient, bryophytes, forest structure, Sierra Nevada del Cocuy, species richness and composition, substrate
\end{abstract}

RESUMO - (Zonação altitudinal de musgos no oeste da Sierra Nevada del Cocuy, Boyacá, Colombia). Este estudo foi realizado com populações de briófitas, a fim de estudar a presença e de como as populações mudam nos gradientes altitudinais. Os musgos foram escolhidos como modelo para realizar este estudo, pois apresentam alta sensibilidade às condições climáticas e ampla distribuição. A região oeste da Sierra Nevada del Cocuy, Boyacá, Colombia possui clima e ecossistemas diferenciados devido à sua complexa topografia. Parcelas em cada $200 \mathrm{~m}$ alt. foram instaladas a partir do pico do Monte Mahoma a $4.200 \mathrm{~m}$ alt. ao sul do desfiladeiro do rio Chicamocha a $1.200 \mathrm{~m}$ alt. A diversidade e a cobertura do solo, da rocha e da casca foram analisadas em cada parcela. Foram encontradas 80 espécies distribuídas em 29 famílias, sendo Pottiaceae e Brachytheciaceae as famílias mais diversas. Nossos resultados mostram uma tendência à diversidade e a cobertura aumentar com a altitude. Observamos cinco faixas altitudinais com três populações definidas pelas espécies de musgos. As faixas Páramo e Superpáramo são as mais ricas.

Palavras-chave: bryophytes, estrutura florestal, gradiente altitudinal, riqueza e composição de espécies, Sierra Nevada del Cocuy, substrato

\section{Introduction}

The knowledge of richness, abundance and distribution of species and how they are assembled along the altitudinal gradients help to promote the long-term conservation of natural species (Korner 2007). Zoning studies help to determine the distribution of biological populations by sampling zones in altitudinal belts where specific ecological characteristics of the site have been described (Kessler 2000). The belt classification of bryophytes has been widely studied and several schemes have been proposed with terminology that varies with the region of the geographical studied area (Frahm \& Gradstein 1991)

Floristic composition in montane ecosystems, the distribution of the plants in them, and the factors that influence the local diversity provide us data to study the

1. Universidad Distrital Francisco José de Caldas, Carrera 7 No. 40B - 53 (Nueva Dirección), Bogotá D.C., República de Colombia

2. Instituto de Botânica, Avenida Miguel Stéfano, 3687, 04301902 São Paulo, SP, Brasil

3. Corresponding author: denilsonfperalta@gmail.com 
relationships between species diversity and climate change (McCain \& Grytnes 2010, Graham et al. 2014, Nascimbene $\&$ Spitale 2017) and can be used to improve conservation strategies (Socolar et al. 2016).

Colombia has a relatively stable climate, in the tropical zone, with its temperature ameliorated by the relief of the Andes mountain range. This mountainous complex provides a variety of environmental conditions that drives the diversification of species, and to date more than 27,000 species of plants and lichens are known to exist in this area (Bernal et al. 2015). Boyacá has the highest mountains in Colombia and has a relief so abrupt that just within a few kilometers several thermal floors strongly differentiated by vegetation and temperature can be found (Governación de Boyacá 2018, IGAC 2008, León et al. 2000).

Mosses are very important plants within the Andean ecosystems because they fulfill vital functions such as water regulation, generation of organic matter, nitrogen fixation and soil protection (Churchill \& Linares 1995, Glime 2001, Slack 1988). They are high diversified in tropical environments (Gradstein et al. 2001, Churchill \& Linares 1995) and widely known to be bioindicators (Proctor $\&$ Tuba 2002) by their sensitivity to heavy metals (Taylor 1919, Glime 1994), soil acidity (Clymo 1987), air quality (Simijaca et al. 2014), water quality (Martínez-Abaigar et al. 1993), and UV-B radiation (Searles et al. 2002). Due their simple anatomy they can be extremely affected by environmental changes (Spitale 2016, Proctor 1990) thereby aiding in the evaluation and classification of altitudinal belts of environmental quality (Kessler 2000).

Mosses also play a wide range of interactions with other species in the ecosystem as they contribute to the renewal of forests by facilitating seed germination (Glime 2001 ), and by providing protection and food to several invertebrate groups (Gerson 1982, 1984, Glime 1994). Bryophytic relationships with roots and mycorrhizae form complex assemblages in some areas, achieving equilibrium in the ecosystem (Cornelissen et al. 2007). These features are totally related to altitudinal gradients due to changes in humidity, temperature and soil (Stehn et al. 2010).

Generally species richness increases with altitude, which is typically related to an increase in humidity (Lee \& Roi 1979), microclimate variables (Raabe et al. 2010) and the variety of available substrates (Mills \& Macdonald 2005). These variables influence moss communities more than forest structure (Márialigeti et al. 2009) even though bryophytes show tolerances to extreme conditions (Bruun et al. 2006).

The type of substrate has been widely discussed although it has been suggested that some species are substrate specialists (Söderström 1988, 1993) and others generalists (Frego \& Carleton 1995). Substrate colonization preference is mediated by the response of mosses to the assemblages related to the micro- and macrohabitat, they are indicative of the importance of the microtopography of the substrate and the degree of light with respect to the gradient (Halpern et al. 2014).

Epiphytic mosses are more influenced by altitudinal gradient than terrestrial mosses (Spitale 2016, Chen et al. 2017). Halpern et al. (2014) emphasized the importance of including all substrate colonized in order to understand the abundance and diversity of bryophytes in forests once studies with this focus were carried out over very small altitudinal gradients and in countries with different climates in latitudes far from the Neotropics. The zonation of bryophytes was studied in Latin America by Wolf (1993), Van Reenen \& Gradstein (1983), Gradstein \& Frahm (1987), Frahm \& Gradstein (1991), and Kessler (2000), Santos \& Costa (2010) but no such study has been made in the eastern hills of Colombia.

This study compares the diversity of mosses along an altitudinal gradient on the west slope of the Sierra Nevada del Cocuy (Boyacá, Colombia). The aim is to determine the replacement and composition of species by means of a Bray-Curtis analysis (cluster) and to understand the variables that influence the distribution of mosses in this region by means of a multivariate analysis.

\section{Material and methods}

Study area and sampling design - Boyacá is a department located in the center of Colombia on the eastern mountain range of the Andes, its northern border is with Santander and there it hosts a mountainous complex called the Serranía del Cocuy with the tallest mountains of Colombia. This site has an enormous variety of ecosystems and climates due to its relief that ranges from 1,000 to $5,500 \mathrm{~m}$ a.s.l., the highest point is the top of Mount Mohammed at west side of the Sierra Nevada del Cocuy. This site includes the rural area of the municipalities of Cocuy, Panqueba, Guacamayas, El Espino and Boavita. The lowest points converge at the Chicamocha River, where it crosses the canyon south of the municipality of Tipacoque at 1,200 m a.s.l. (IGAC 2008).

Collections were made along an altitudinal gradient from 1,200 to $4,200 \mathrm{~m}$ a.s.l., the sampling plots (with 2 plots of $10 \times 10 \mathrm{~m}$ on soil, rock and 10 tree trunks with a diameter at breast height - DBH - greater than $10 \mathrm{~cm}$ ) were established every 200 altitudinal meters, with a total of 16 sampling points (figure 1). We collected data of relative humidity, temperature, vegetation characteristics, disturbance aspects, proximity to water tributaries among other aspects, following the methodology of BRYOLAT for altitudinal studies (Frahm \& Gradstein 1991, Ah-Peng et al. 2014, Hernández-Hernández et al. 2017). 

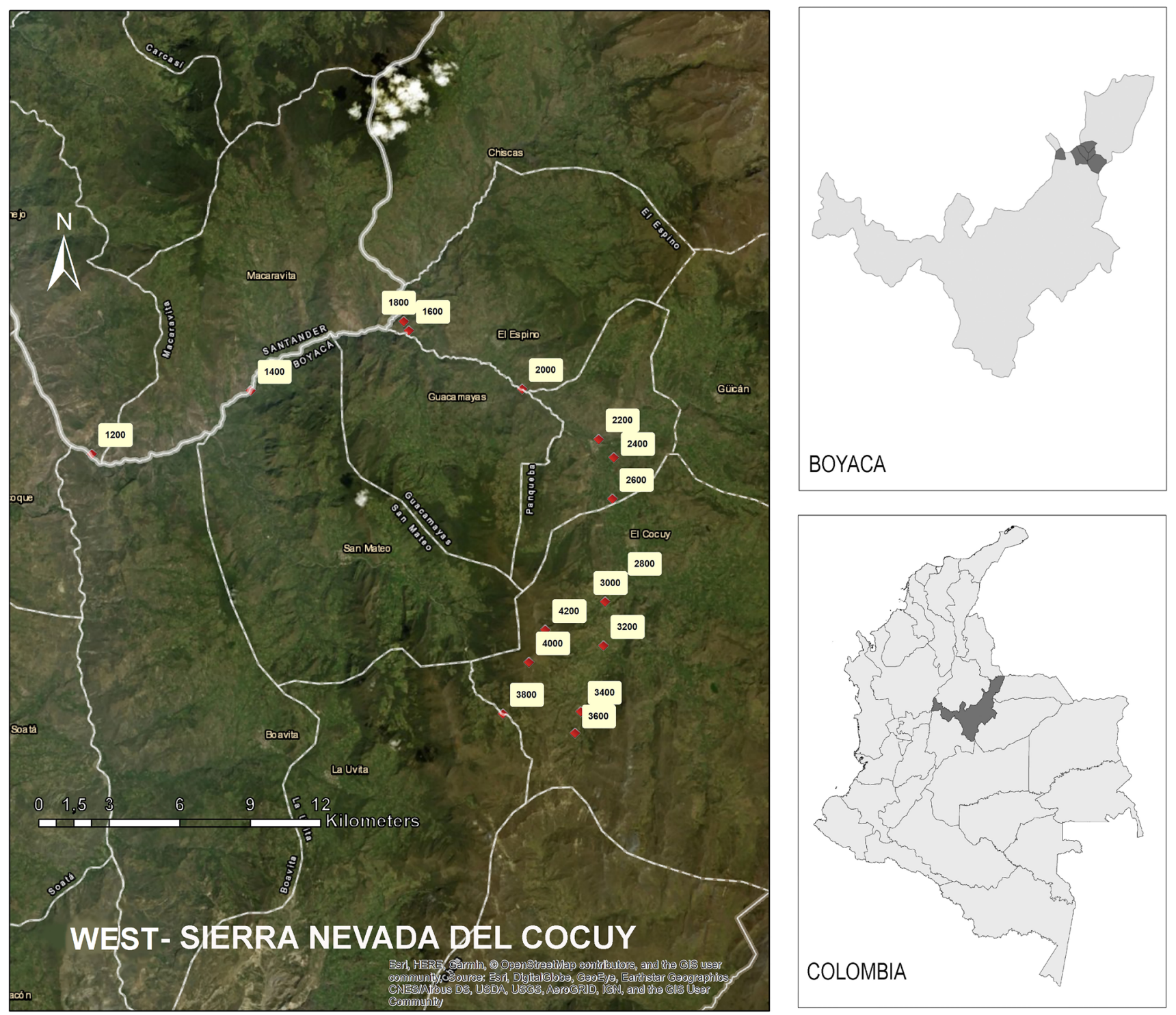

Figure 1. Location of the 16 points in the sampling area within the municipalities of El Cocuy, Panqueba, El Espino, Guacamayas and San Mateo, Department of Boyacá, Colombia.

Description and characterization of the altitudinal belts Superpáramo (3,800 4,200 m a.s.l.) (figure 2 a): These areas have scarce vegetation that grows on rocks and sandy soils at the snow line. It is at the limit of three páramo zones: the temperatures are extreme and frequently dip to the freezing point, precipitation is incessant, winds often reach high speeds. Due to the extreme environmental conditions, access to these areas is difficult and thus there has been little disturbance by man. The superpáramo contains a very high level of endemism (Baruch 1984, Cleff 1978). There are no arboreal phorophytes, only small shrubs of Polylepis, Pentacalia and Espeletia, species of the family Ericaceae and Asteraceae, and large grasslands dominated by the genera Calamagrostis and Agrostis growing among rocks on the peaks of the mountains. Páramo (3,200 3,600 m a.s.l.) (figure 2 b): Tropical Subalpine Forest (Gradstein \& Frahm
1987), fourth thermal floor (Van Reenen \& Gradstein 1984), Subalpine Forest (Frahm 1990). This area is a particular tropical ecosystem characterized by low temperatures, high atmospheric pressure, intense radiation, high humidity and extreme changing conditions (Cuatrecasas 1968, Van der Hammen \& Cleef 1986). The vegetation of the páramos comprises areas of low shrubs known as "pajonales" and "frailejonales" with Espeletia, Puya, Polylepis, Pentacalia, Gynoxys, Werneria and Aciachne. Subpáramo (2,600 3,000 m a.s.l.) (figure $2 \mathrm{c}$ ): High tropical montane forest (Gradstein \& Frahm 1987, Frahm 1991), third thermal floor (Van Reenen \& Gradstein 1984), tropical subalpine forest (Frahm \& Gradstein 1991). This is a transition zone between the high Andean forest and the páramo, characterized by being very humid and dominated by low shrubs such as the genus Baccharis, Hypericum, Gaultheria and Sambucus. 

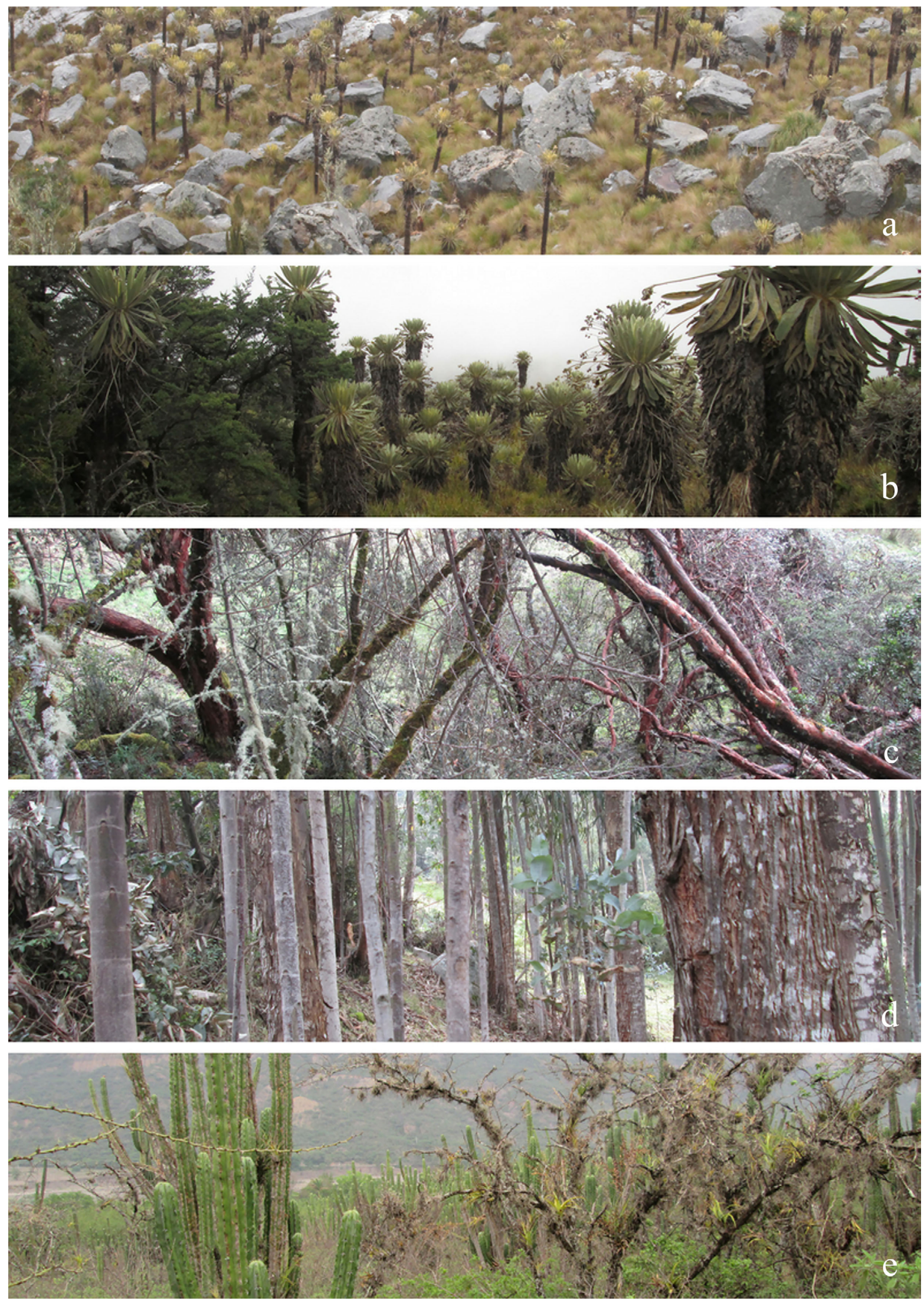

Figure 2. Zonal outline of the different sampling points. a. Superpáramo. b. Páramo. c. Subpáramo. d. High Forest. e. Low Montane Forest, Department of Boyacá, Colombia. 
However, there are also scattered and isolated patches of forest that are dominated by the genera Miconia, Escallonia, and Diplostephium with height not exceeding $10 \mathrm{~m}$ (Cuatrecasas 1934, 1958). These areas are threatened by deforestation for agricultural exploitation and the creation of pastures for cattle grazing. High Andean forest (2,000 2,400 $\mathrm{m}$ a.s.l.) (figure $2 \mathrm{~d}$ ): Tropical montane forest (Gradstein \& Frahm 1987, Frahm 1991), second thermal floor (Van Reenen \& Gradstein 1984), Andean forest (Cuatrecasas 1958), high montane tropical forest (Frahm \& Gradstein 1991). In these zones the climate becomes more temperate, plant cover increases considerably, and soils have a large amount of humid organic matter (Frahm \& Gradstein 1991). The ground is sometimes covered with large grazing areas and epiphytic moss mats become prominent in the areas of woody vegetation of a greater height, dominated by trees of the genera Escallonia, Salix, Quercus, Pinus, Eucalyptus, Schinus and Acacia. These areas are strongly influenced by the presence of the Nevado River, with riparian forests among the tributaries and fog at the highest points. The mosses of this area are important for the conservation of water resources; they also contribute to the preservation of microhabitats for microfauna and facilitate seed germination of native species (Cornelissen et al. 2007). Montane-low forest (1,200 1,800 m a.s.1.) (figure $2 \mathrm{e}$ ): Submontane tropical forest (Gradstein \& Frahm 1987, Frahm 1991), first thermal floor (Van Reenen \& Gradstein 1984), lowlands (Grubb $\&$ Whitmore 1967). This area consists primarily of very dry, desert areas of high temperatures with thorn scrubtype xerophytic to subxerophytic vegetation, although there are also forest types in the highest or transitional sites (Cuatrecasas 1958). The soils lack organic matter, and some authors have highlighted the presence of arid, cardonal pajonales and a vegetation typical of dry forests (Hernández et al. 1992, Rangel 1995). These forests contain a great diversity of cacti with Opuntia, Wigginsia, Mammillaria and Echinopsis; the common low trees are Prosopis, Mielochia, Schinus, Gyrocarpus, and Lipia, and grasses like Cyperus. This vegetation type has similarities with the tropical dry forest located towards the Caribbean coast and in the Patia Valley (Albesiano \& Rangel 2006).

Collection and data analysis: The coverage of each of the samples were taken with a transparent acetate template of $20 \times 22 \mathrm{~cm}$ with $1 \mathrm{~cm}$ quadrants (modified from Iwatsuki 1960). Specimens collected were air-dried (Churchill \& Linares 1995, Gradstein et al. 2001) and deposited in the herbarium of Universidad Distrital "Francisco José de Caldas" (UDBC).

Specimen determinations follow Churchill \& Linares (1965), Zander (1972), Monte (1977). Griffin \& Morales (1983), Cárdenas (1995), Duarte (1997), Gradstein et al. (2001), Muñoz (1999), Allen (2002), Calabrese (2006) and Frahm (1991).
A matrix was constructed with: Sample number, coverage, coordinates, substrate, humidity, temperature, description of ecosystem and type of soil. R program was used to determine the relationships between the species and the zones based on Simpson and Shannon indexes and the clusters using Bray-Curtis similarity index. PCord program was carried out in order to establish which variables are affecting the composition and structure of the mosses in each altitudinal belt.

\section{Results}

A total of 752 samples were collected from the 16 established sampling plots. We found 29 families and 80 species (table 1), including eight new records to Colombia and 36 for Boyacá according to the list of Gradstein et al. (2018). $65 \%$ of the species correspond to acrocarps and most are found on soils and rocks. The highest host specificity was found in epiphytes, and the families with the most species richness are Pottiaceae (15 spp.) and Brachytheciaceae (10 spp.). The composition of the forest along the altitudinal gradient $(4,200$ $\mathrm{m}$ a.s.l. to $1,200 \mathrm{~m}$ a.s.1.) was marked by five altitudinal belts: superpáramo, páramo, subpáramo, high-Andean forest and low montane forest.

Variations in diversity and coverage along the altitudinal gradient The Shannon and Simpson diversity and abundance indices show that diversity has a tendency to increase with altitude. Páramo and superpáramo (figure 3) show the highest values, which reaffirms the importance of the conservation of these ecosystems and the value that this region has at an ecological level (Cleef 1978, Luteyn 1992). The diversity of mosses on soil in all the altitudes was greater than that of the epiphytes because terrestrial mosses are less subject to climatic variability (Spitale 2016, Spitale 2016). In the literature the increase in altitude is associated with lower temperatures, more humid and cloudy climates; these ecological characters are optimal for a great diversity of mosses (Lee \& Roi 1979, Kessler 2000, Bruun et al. 2006).

The Simpson indices show a lower dominance of species in the highest belts ( $36004200 \mathrm{~m})$ and a high dominance in the lowest belts (1200 1600 m) (figure 4). The low belts have a low presence of species because of dry forest conditions with Pseudocrossidium replicatum dominating on soil and Fabronia ciliaris as the dominant epiphyte.

Cover analysis - The moss cover in low montane forests has a low value in comparison with the other altitudinal belts, since at 2,200 $\mathrm{m}$ there is a remarkable increase in moss cover with it decreasing only when reaching the superpáramo (figure 5). This trend in cover was also observed by Van Reenen \& Gradstein (1983) in the Sierra Nevada of Santa Marta and Frahm (1990) in Borneo. 
Table 1. Species of mosses present in the west of the Sierra Nevada of Cocuy, Boyacá, Colombia.

\begin{tabular}{|c|c|c|c|}
\hline Species & Growth form & Substrate & Altitud (m a.s.l.) \\
\hline Anacolia laevisphaera (Taylor) Flowers & Acrocarpic & Rock-Soil & $4000-3600-3400-2000-1600$ \\
\hline Andreaea rupestris Hedw. & Acrocarpic & Rock & 4200 \\
\hline Anomobryum prostratum (Müll. Hal.) Besch. & Acrocarpic & Soil & 3400 \\
\hline Barbula integrifolia (R.S. Williams) R.H. Zander & Acrocarpic & Bark & 3800 \\
\hline Brachymenium klotzchii (Schwägr.) Paris & Acrocarpic & Bark & 2400 \\
\hline Brachytecium conostomun (Taylor) A. Jaeger & Pleurocarpic & Soil & 3600 \\
\hline Brachythecium plumosum (Hedw.) Schimp. & Pleurocarpic & Bark-Rock-Soil & $3400-3000-2600$ \\
\hline Brachythecium poadelphus Müll. Hal. & Pleurocarpic & Soil & 3600 \\
\hline Brachythecium ruderale (Brid.) W.R. Buck & Pleurocarpic & Bark-Rock-Soil & $3000-2800-2000$ \\
\hline Brachythecium rutabulum (Hedw.) Schimp. & Pleurocarpic & Soil-Rock & $3800-3000-2600$ \\
\hline Brachythecium sp. & Pleurocarpic & Soil & 3000 \\
\hline Breutelia polygastrica (Müll. Hal.) Broth. & Acrocarpic & Soil & 4200 \\
\hline Bryum andicola Hook. & Acrocarpic & Bark-Rock-Soil & $\begin{array}{c}4200-4000-3800-3600- \\
3200-3000-2800-2600- \\
2400-2200-2000-1800\end{array}$ \\
\hline Bryum argenteum Hedw. & Acrocarpic & Bark-Rock-Soil & $3600-2600-2400-1800$ \\
\hline Campylopus andersonii (Müll. Hal.) A. Jaeger & Acrocarpic & Rock & 2800 \\
\hline Campylopus fragilis Bruch \& Schimp. & Acrocarpic & Rock -Soil & 1600 \\
\hline Campylopus nivalis (Brid.) Brid. & Acrocarpic & Rock-Soil & 4200 \\
\hline Campylopus sp. & Acrocarpic & Soil & 3200 \\
\hline Catagonium brevicaudatum Müll. Hal. ex Broth. & Pleurocarpic & Bark-Rock & 4200 \\
\hline Chryso-hypnum elegantulum (Hook.) Hampe & Pleurocarpic & Rock & 2000 \\
\hline Cryphaea patens Hornsch. ex Müll. Hal. & Pleurocarpic & Bark & 3200 \\
\hline Cryphaea ramosa (Mitt.) Mitt. & Pleurocarpic & Bark-Soil & $4000-3800-3600-3400$ \\
\hline Daltonia pulvinata Mitt. & Pleurocarpic & Bark & 4000 \\
\hline Dicranum frigidum Müll. Hal. & Acrocarpic & Rock-Soil & 4200 \\
\hline Entodon jamesonii (Taylor) Mitt. & Pleurocarpic & Bark-Rock-Soil & $3600-3200-3000-2000$ \\
\hline Erpodium beccari Müll. Hal. & Pleurocarpic & Bark & $1400-1200$ \\
\hline Erythrodontium longisetum (Hook.) Paris & Pleurocarpic & Bark-Rock & $2600-2400-2200$ \\
\hline Fabronia ciliaris (Brid.) Brid. & Pleurocarpic & Bark-Rock-Soil & $2200-1800-1600-1400-1200$ \\
\hline Fissidens angustelimbatus Mitt. & Acrocarpic & Soil & 2000 \\
\hline Fissidens bryoides Hedw. & Acrocarpic & Soil & $3400-1600$ \\
\hline Fissidens curvatus Hornsch. & Acrocarpic & Soil & 2200 \\
\hline Fissidens palmatus Hedw. & Acrocarpic & Soil & 1600 \\
\hline Fissidens sp. & Acrocarpic & Soil & 1200 \\
\hline Fissidens weirii Mitt. & Acrocarpic & Soil & 2800 \\
\hline Fissidens zollingeri Mont. & Acrocarpic & Soil & 3400 \\
\hline Grimmia donniana Sm. & Acrocarpic & Rock & $\begin{array}{c}3400 \text { (New record to } \\
\text { Colombia) }\end{array}$ \\
\hline Grimmia elongata Kaulf. & Acrocarpic & Soil & $\begin{array}{c}4000-3400 \text { (New record to } \\
\text { Colombia) }\end{array}$ \\
\hline
\end{tabular}


Table 1 (continuation)

\begin{tabular}{|c|c|c|c|}
\hline Species & Growth form & Substrate & Altitud (m a.s.l.) \\
\hline Grimmia fuscolutea Hook. & Acrocarpic & Rock & $\begin{array}{l}\text { 4000-3200 (New record to } \\
\text { Colombia) }\end{array}$ \\
\hline Groutiella chimborazensis (Spruce ex Mitt.) Florsch. & Acrocarpic & Bark & 2000 \\
\hline Hedwigia ciliata (Hedw.) P. Beauv. & Acrocarpic & Rock & $\begin{array}{c}3400-3200(\text { New record to } \\
\text { Colombia) }\end{array}$ \\
\hline Hedwigidium integrifolium (P. Beauv.) Dixon & Acrocarpic & Rock & $\begin{array}{l}4200-4000-3800(\mathrm{New} \\
\text { record to Colombia) }\end{array}$ \\
\hline Hypnum cupressiforme Hedw. & Pleurocarpic & Bark-Rock-Soil & $\begin{array}{l}4200-4000-3800-3600- \\
3400-3200-3000-2800\end{array}$ \\
\hline Leiomela aristifolia (A. Jaeger) Wijk \& Margad. & Acrocarpic & Soil & 4200 \\
\hline Leiomela bartramioides (Hook.) Paris & Acrocarpic & Rock-Soil & $3800-3000-2800-2600-2400$ \\
\hline Leptodontium flexifolium (Dicks.) Hampe & Acrocarpic & Bark-Soil & $4200-4000-3800$ \\
\hline Leptodontium proliferum Herzog & Acrocarpic & Bark & $3600-3400$ \\
\hline Leptodontium sp. & Acrocarpic & Bark-Rock-Soil & $4200-3600-3200-3000$ \\
\hline Leptodontium syntrichioides (Müll. Hal.) Kindb. & Acrocarpic & Bark & $4000-3600$ \\
\hline $\begin{array}{l}\text { Leptodontium viticulosoides (P. Beauv.) Wijk \& } \\
\text { Margad. }\end{array}$ & Acrocarpic & Bark -Rock-Soil & $\begin{array}{l}4200-4000-3800-3600- \\
3200-3000-2800-2600\end{array}$ \\
\hline Lepyrodon tomentosus (Hook.) Mitt. & Pleurocarpic & Bark & $4000-3800$ \\
\hline Leskeadelphus angustatus (Taylor) B.H. Allen & Pleurocarpic & Bark-Soil & $\begin{array}{l}2800-2600-2400-2200- \\
2000-1800-1600\end{array}$ \\
\hline Macrocoma tenuis (Hook. \& Grev.) Vitt & Acrocarpic & Bark-Soil & $2000-1800$ \\
\hline Macromitrium cirrosum (Hedw.) Brid. & Acrocarpic & Bark & $4200-4000-2200$ \\
\hline Macromitrium punctatum (Hook. \& Grev.) Brid. & Acrocarpic & Bark & $3800-2600$ \\
\hline Macromitrium richardii Schwägr. & Acrocarpic & Bark & 3800 \\
\hline Macromitrium scoparium Mitt. & Acrocarpic & Bark & 3600 \\
\hline Macromitrium sp. & Acrocarpic & Bark & $4200-3200$ \\
\hline Meteoridium remotifolium (Müll. Hal.) Manuel & Pleurocarpic & Soil & $2200-2000$ \\
\hline $\begin{array}{l}\text { Meteoridium tenuissimum (Hook. \& Wilson) M.A. } \\
\text { Lewis }\end{array}$ & Pleurocarpic & Bark & 4000 \\
\hline Neckera ehrenbergii Müll. Hal. & Pleurocarpic & Bark & $\begin{array}{l}4000-3800-3600-3200- \\
3000-2000\end{array}$ \\
\hline Palamocladium leskeoides (Hook.) E. Britton & Pleurocarpic & Bark-Soil & $4200-4000$ \\
\hline Philonotis sp. & Acrocarpic & Soil & 1400 \\
\hline Pleurochaete squarrosa (Brid.) Lindb. & Acrocarpic & Soil & 2400 \\
\hline Polytrichum juniperinum Hedw. & Acrocarpic & Soil & $4200-4000-3800$ \\
\hline Prionodon densus (Sw. ex Hedw.) Müll. Hal. & Pleurocarpic & Bark & 4000 \\
\hline Pseudocrossidium replicatum (Taylor) R.H. Zander & Acrocarpic & Soil & $1800-1600-1400-1200$ \\
\hline Racomitrium crispipilum (Taylor) A. Jaeger & Acrocarpic & Soil & 4200 \\
\hline Rhacocarpus purpuracens (Brid.) Paris & Pleurocarpic & Soil & 4200 \\
\hline Rhynchostegium scariosum (Taylor) A. Jaeger & Pleurocarpic & Bark & $3800-3400$ \\
\hline Rhynchostegium serrulatum (Hedw.) A. Jaeger & Pleurocarpic & Soil & $3000-3800-4000$ \\
\hline Sematophyllum subpinnatum (Brid.) E. Britton & Pleurocarpic & Bark-Soil & $3600-1600$ \\
\hline
\end{tabular}


Table 1 (continuation)

\begin{tabular}{lccc}
\hline Species & Growth form & Substrate & Altitud (m a.s.1.) \\
\hline Streptocalypta lorentziana Müll. Hal. & Acrocarpic & Soil & $\begin{array}{c}1600 \text { (New record to } \\
\text { Colombia) }\end{array}$ \\
Synthrichia lacerifolia (R.S. Williams) R.H. Zander & Acrocarpic & Rock & $\begin{array}{c}2600 \text { (New record to } \\
\text { Colombia) }\end{array}$ \\
Syntrichia andicola (Mont.) Ochyra & Acrocarpic & Bark-Soil & 3600 \\
Syntrichia fragilis (Taylor) Ochyra & & & $3600-3400-3200-3000-$ \\
& Acrocarpic & Bark-Rock-Soil & $2800-2400-2200-2000-$ \\
Syntrichia laevipila Brid. & & & $1800-1400$ \\
Syntrichia sp. & Acrocarpic & Rock & 3600 (New record to \\
Thuidium delicatulum (Hedw.) Schimp. & Acrocarpic & Rock & Colombia) \\
Thuidium peruvianum Mitt. & Pleurocarpic & Bark-Rock-Soil & $4200-4000-3800-3600-$ \\
Zygodon sp. & Pleurocarpic & Bark-Soil & 2000 \\
\hline
\end{tabular}

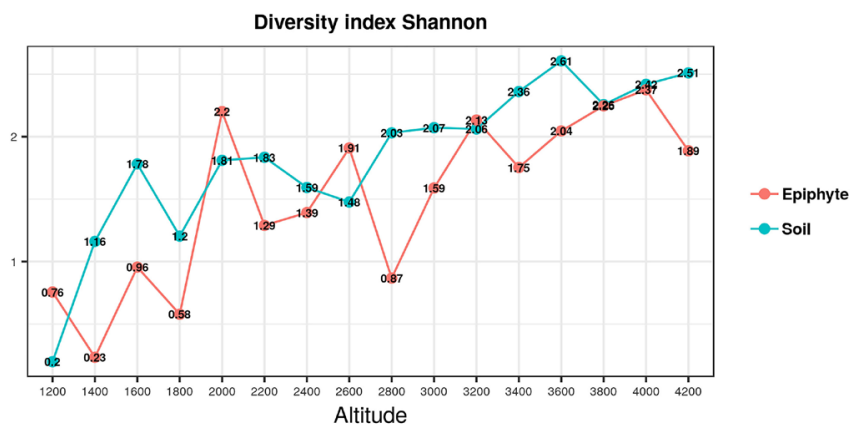

Figure 3. a. Behavior of the specific diversity index (ShannonWienner) along the altitudinal gradient. b. Specific diversity index (Shannon-Wiener) comparing epiphytic and soil mosses along the altitudinal gradient.

The moss cover shows an increase with altitude from the low montane forest to the high Andean forest with similar curves for soil and epiphytic substrates, and only at the páramo and superpáramo does the cover on soil become greater than that of epiphytic habitats (figure 6).

The Two-way analysis of Bray-Curtis (figure 7 a) shows well the structure in relation to the altitudinal zoning. Basically three groups are formed: (1) low montane forest (2) Andean high forest and parts of the sub-paramo and páramo (3) superpáramo and parts of the páramo. The zones with more unique elements correspond to the lower zones and the highest ones of the altitudinal gradient. The intermediate zones do not seem to have unique phytotaxonomic elements but rather the species composition is the result of the replacement and overlap of species from the surrounding altitudinal belts.

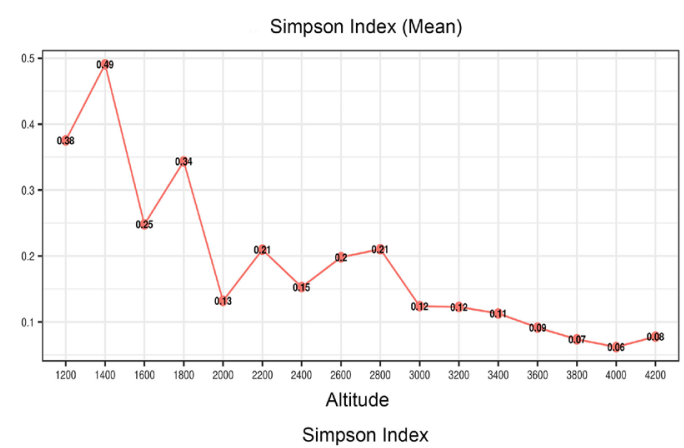

$\mathrm{a}$

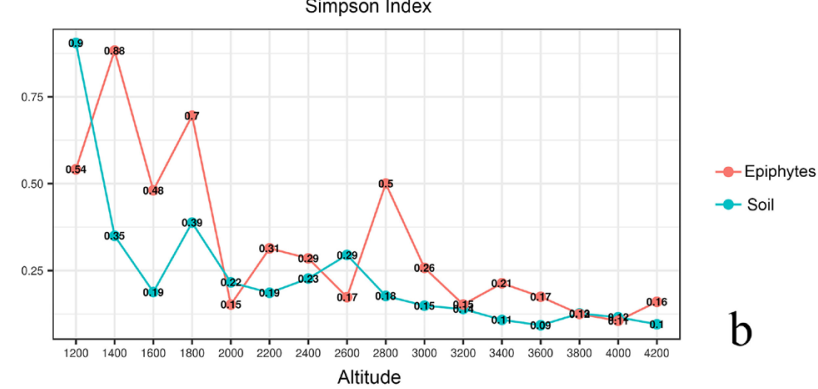

Figure 4. a. Species dominance (Simpson's Index) total along the altitudinal gradient. b. Species dominance (Simpson's Index) for epiphytic and soil mosses along the altitudinal gradient.

Cluster Analysis of the species at altitude belts studied shows interrelationship associations between nearby plots and it does not clearly differentiate the belts studied and the confidence is greater than 0.5 (figure $7 \mathrm{~b}$ ).

A multidimensional scale ordering (figure 8) comparing the abundances of the species in the altitudinal ranges sampled (Bray-Curtis) shows a structural map of the altitudinal zoning, where the mosses located east of the Sierra 


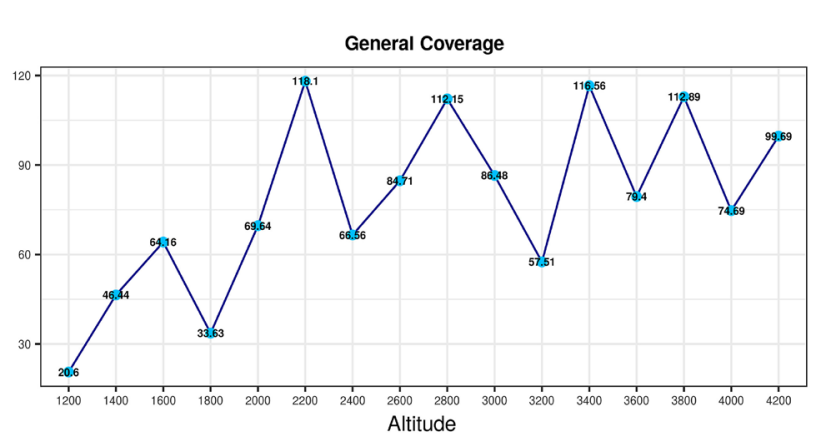

Figure 5. Total coverage of all species present at each altitudinal belt, Department of Boyacá, Colombia.

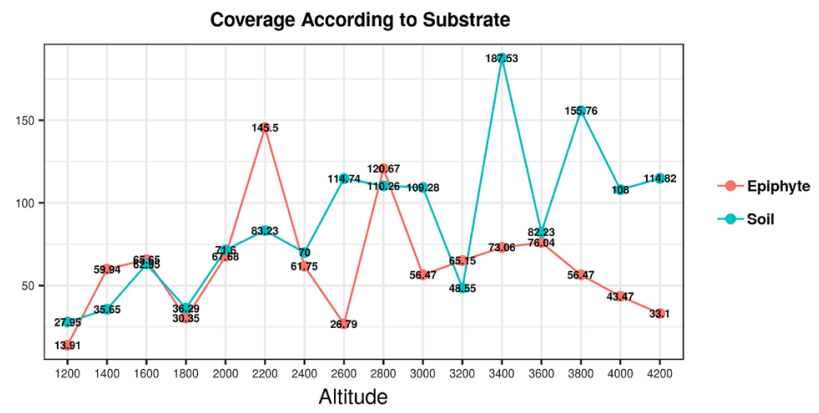

Figure 6. Average coverage of epiphytic and soil mosses for each altitudinal point, Department of Boyacá, Colombia.

Nevada de Cocuy have a fairly distributed dominance due to their large number of species and their variety of ecosystems. Indicator species of altitudinal or ecosystem conditions are pointed out, and some of these have been recognized in the literature, such as Erpodium beccarii indiative of dry tropical forests; the genera Leptodontium, Grimmia and Andreaea as typical to the páramos; and the genera Brachymenium, Erythrodontium and Brachythecium characteristic of humid tropical forests (Hernandez \& Sanchez 1992: Churchill \& Linares 1995).

The overlap of species between the altitudinal ranges show the assemblages among the niches available for the ecotone. There are three groups that share environmental characteristics and correspond to the species of low montane forest, high Andean forest and the páramos: the species with greater altitudinal ranges are acrocarpous ones from the families Pottiaceae, Bryaceae and Bartramiaceae (Stehn et al. 2010).

The analysis of canonical components of the vegetation shows the páramos (figure 9 a) as the richest in environmental variables with correspondingly greater diversity because they seem to be optimal for the growth and dispersal of mosses (Cleef 1978, Proctor et al. 2007, Glime 2017). Populations of low montane forest show a small group of mosses isolated from the rest due to habitat's high temperatures, low humidity and characteristic tropical dry forest vegetation (Albesiano et al. 2003, Smith \& Stark 2014). The High Andean forest seems to contain a transitional or overlapping group of species between other altitudinal belts, with species adapted to temperate and warm climates as well described by Proctor (2000), Smith \& Stark (2014) and Glime (2017) for species of dry ecosystems forming populations separated from the common niche.

The analysis of canonical components of the substrates (figure $9 \mathrm{~b}$ ) shows relationships between the lower temperatures and higher humidity with rocks and soils clearly related to the large quantity of rocks and humus-rich, humid soils and the frequent fog at high elevations. The low relationship with the epiphytic species is because phorophyte size decreases with altitude, and woody substrates are more frequently colonized in low montane forests with dry conditions and generalists without a preferred substrate. This analysis shows how the populations of mosses distributed by substrate do not have a clear relation with environmental variables but rather their distribution is mediated by the availability of the resources found (Spitale 2016, Spitale 2017) within the type of forest and the geographical conditions of the place.

Description of communities and altitudinal belt exclusive mosses - Superpáramo (3,800 4,200 m a.s.l.): The coverage of mosses represents $23 \%$ of the total sampled with the superpáramo being the most diverse altitudintal belt with 21 families (Hypnaceae, Pottiaceae, Macromitriaceae, Neckeraceae, Brachytheciaceae, Bryaceae, Thuidiaceae, Bartramiaceae, Polytrichaceae, Dicranaceae, Cryphaeaceae, Grimmiaceae, Orthotrichaceae, Meteoriaceae, Lepyrodontaceae, Daltoniaceae, Prionodontaceae, Rhacocarpaceae, Catagoniaceae, Hedwigiaceae and Leucobryaceae). The highest indices were found at 4,000 $\mathrm{m}$ a.s.l. The coverage of epiphytic mosses is minimal due the scarce number of phorophytes. The indicator species exclusively found in this belt are Racomitrium crispipilum, Leptodontium flexifolium, Macromitrium punctatum, Lepyrodon tomentosum, Leptodontium synthrichioides, Andreaea rupestris and Grimmia elongata.

Páramo (3,200 3,600 m a.s.1.): The coverage of mosses at this point remains stable at $23 \%$ of the total sample. The bryophytic epiphytes show a greater coverage with 17 families (Entodontaceae, Leucobryaceae, Hypnaceae, Leskeaceae, Pottiaceae, Hedwigiaceae, Grimmiaceae, Dicranaceae, Bryaceae, Neckeraceae, Brachytheciaceae, Cryphaeaceae, Macromitriaceae, Bartramiaceae, Fissidentaceae, Thuidiaceae, and Sematophyllaceae). The indicator species exclusive of this belt are Hedwigia ciliata, Anomobryum prostratum, Syntrichia laevipila, Grimmia fuscolutea and Cryphaea ramosa.

Subpáramo (2,600 3,000 m a.s.l.): The diversity of mosses increases slightly with respect to the high Andean forest in subpáramo. The epiphytic strata have less species than those of the soil; the coverage at this point represents $23 \%$ 
a

\section{Cluster Altitude}

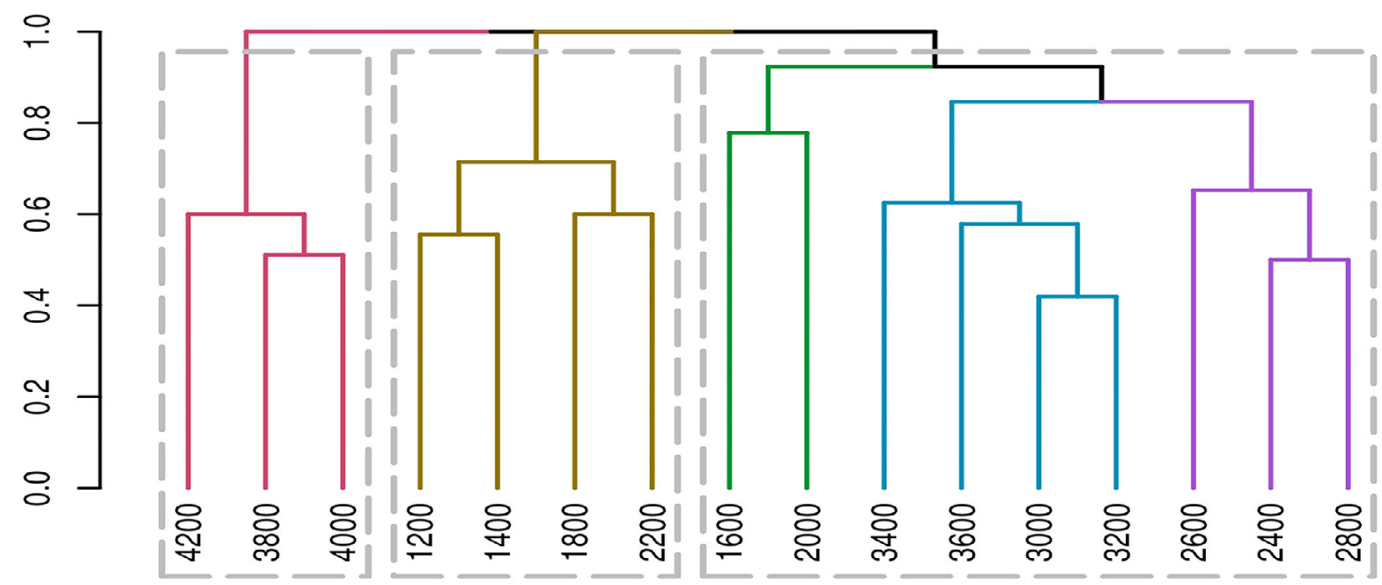

b
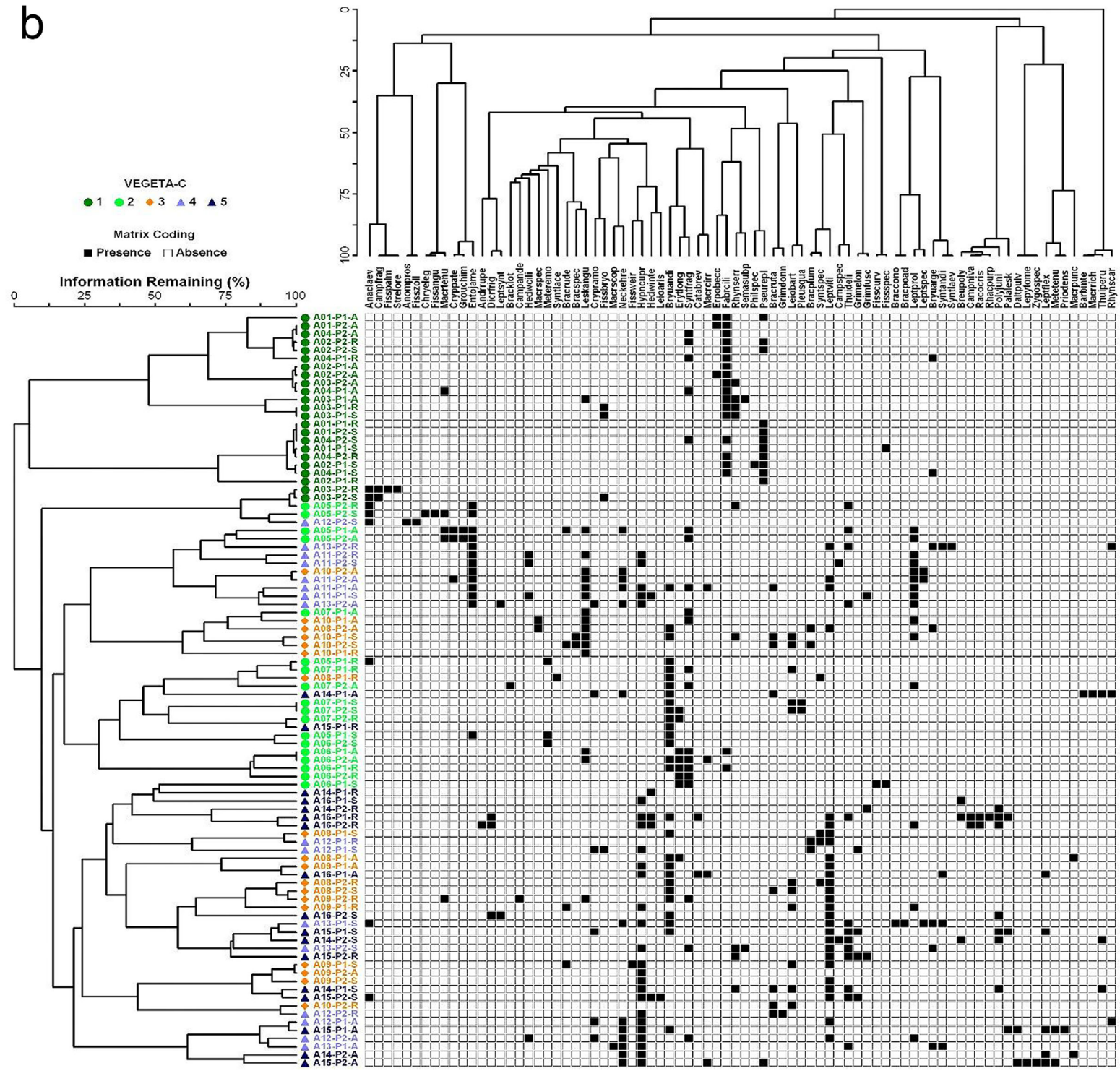

Figure 7. a. Cluster of altitudinal points (similarity index of Bray-Curtis). b. Analysis of presences and absences (Two-way) of Bray-Curtis. 
Rhacocarpus purpuracens (Brid.) Paris -

Racomitrium crispipilum (Taylor) A. Jaeger Leiomela aristifolia (A. Jaeger) Wijk \& Margad. Dicranum frigidum Müll. Hal. Campylopus nivalis (Brid.) Brid. Breutelia polygastrica (Mül. Hal.) Broth. Andreaea rupestris Hedw. -

Palamocladium leskeoldes (Hook.) E. Britton Hedwigidium integrifollum Zygodon sp. Hook. \& TaylorPrionodon densus (Sw, ex Hedw.) Moll. Hal. Polytrichum juniperinum Hedw. Meteoridium tenuissimum (Hook. \& Wison) M.A. Lewis Leptodontium fiexifolium (Dicks) Hampe Daltonia pulvinata Mitt Lepyrodon tomentosus (Hook.) Mitt Thuidium peruvianum Mitt Macromitrium richardil Schwägr. Leptodontium syntrichloldes (Mül. Hal.) Kindb. Barbula Integrifolla (R.S. Willams) R.H. ZanderGrimmia elongata Kaulf. Cryphaea ramosa (Mitt.) Mitt. Syntrichia laeviplia Brid. Syntrichia andicola (Mont) Ochyra Rhynchostegium serrulatum (Hedw.) A. Jaeger Rhynchastegium scariosum (Taylor) A Jaeger Macromitrium scoparium Mitt. Grimmia fuscolutea Hook. Brachythecium poadelphus Môll. Hal. Brachytecium conostomun (Taylor) A. Jaeger Thuidium dellcatulum (Hedw.) Schimp. Leptodontium proliferum Herzog -

Hypnum cupressiforme Hedw. -

Macromitrium cirrosum Hedw.) Brid. Leptodontium viticulosoides ( $P$. Beauv) Wijk \& Margad. Grimmia donniana Sm. Fissidens zollingeri Mont Anomobryum prostratum (Müll. Hal.) Besch. Hedwigia cillata Neckera ehrenbergli Moll. Hal. Macromitrium punctatum (HoOK. \& Grev.) Brid. Brachythecium rutabulum (Hectw.) Schimp. Brachythecium plumosum (Hedw.) Schimp. Bryum andicola Hook. Entodon jamesonil (Taylor) Mitt Leiomela bartramioides (Hook.) Paris Anacolia laevisphaera (Taylor) Flowers Fissidens weirii Mitt. Campylopus andersonii (Mülı. Hai.) A. Jaeger Synthrichia lacerifolla (R.S. Willams) R.H. Zander Sematophyllum subpinnatum (Brid.) E. BrittonCryphaea patens Hornsch. ex Moll. Hal. Bryum argenteum Hedw. Syntrichla fragilis (Taylor) OchyraFissidens bryoides Hedw. Brachythecium ruderale (Brid.) W.R. BuckPleurochaete squarrosa (Brid.) Lindb. Erythrodontium iongisetum (Hook.) Paris Brachymenium klotzchil (Schwägr.) Paris Leskeadelphus angustatus (Taylor) B.H. AllenFissidens curvatus Homsch. Meteoridium remotifolium Müll. Hal.) Manuel Groutiella chimborazensis (Spruce ex Mitt.) Florsch. Fissidens angustelimbatus Mitt Chryso-hypoum elegantulum (Hook.) Hampe Fabronia cilliaris (Brid.) Brid. Macrocoma tenuis (Hook \& Grev.) VittStreptocalypta lorentziana Mül. Hal. Fissidens palmatus Hedw. Campylopus fragilis Bruch \& Schimp. Pseudocrossidium replicatum (Taylor) R.H. Zander Philonotis sp. Brid. Empodium beccari Müll. Hal. -

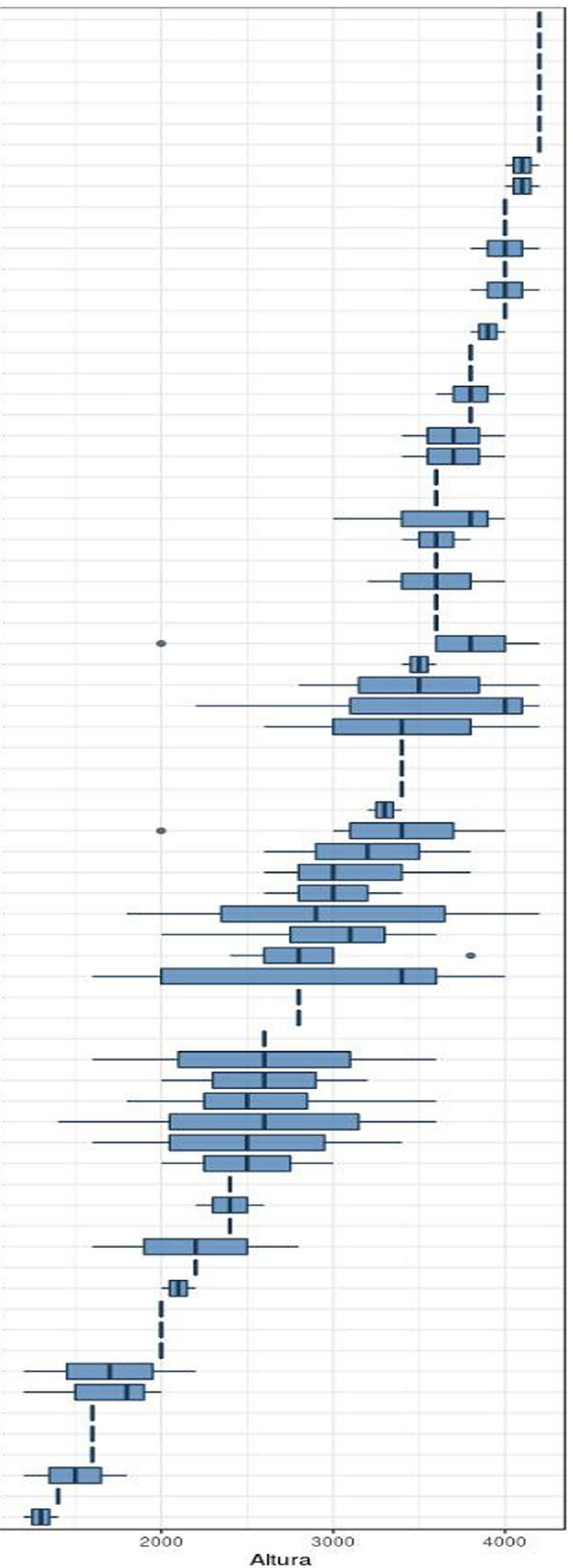

Figure 8. Ordination of species on a multidimensional scale using Bray Curtis. 


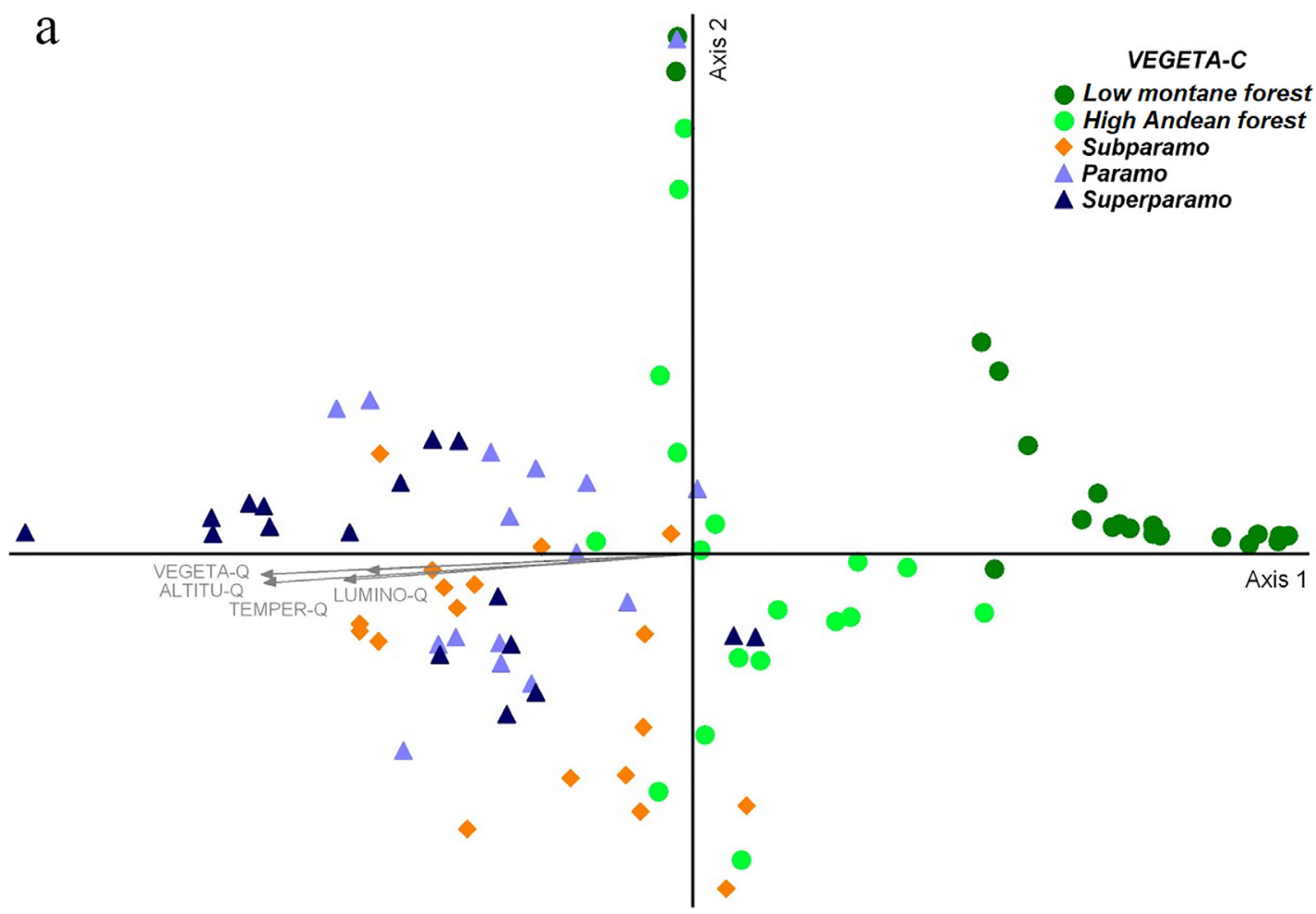

b

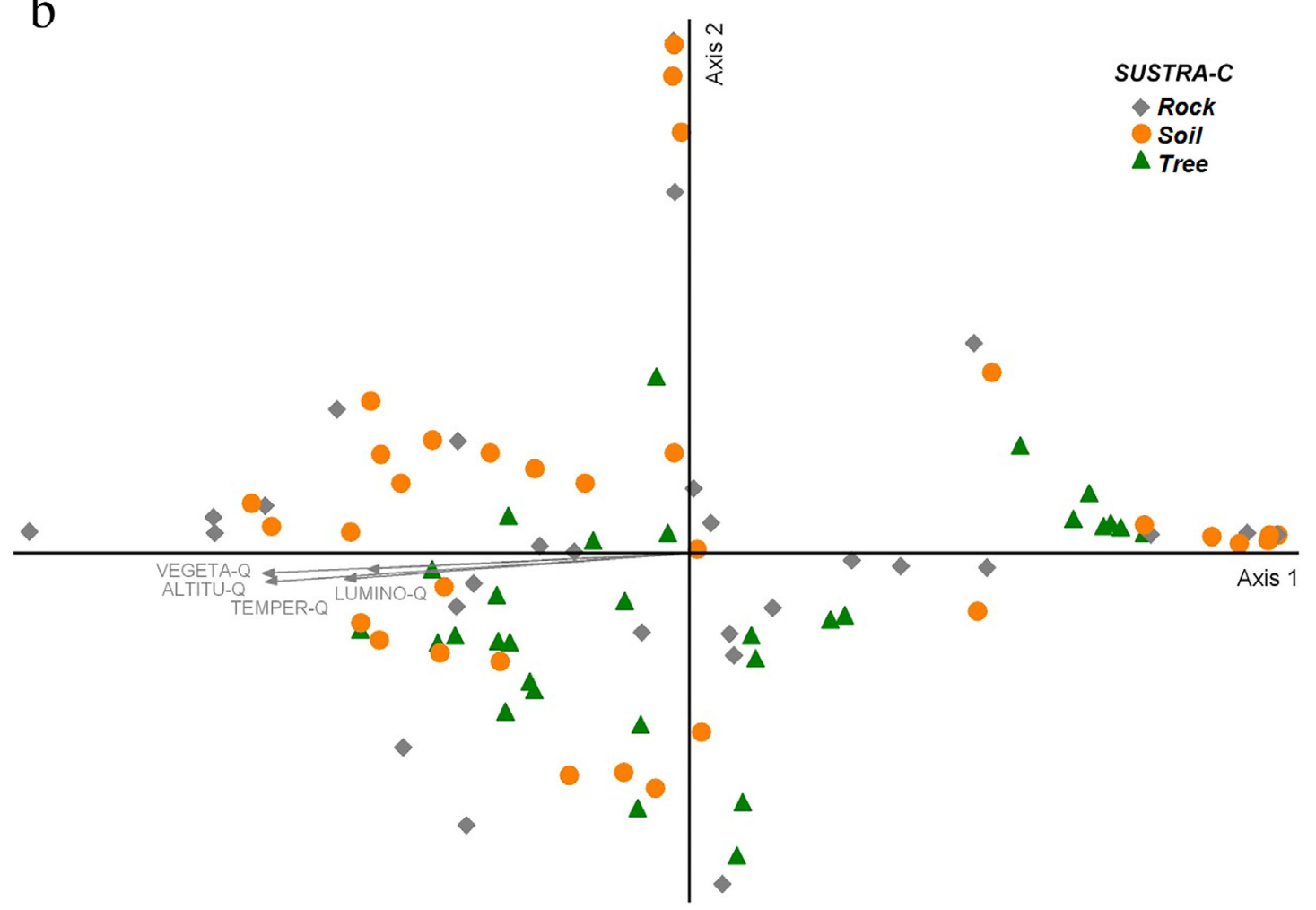

Figure 9. Analysis of canonical components. a. For altitudinal belts. b. For substrate. 
of the sample and is represented mostly by soil mosses with 10 families (Pottiaceae, Bryaceae, Brachytheciaceae, Leskeaceae, Macromitriaceae, Entodontaceae, Hypnaceae, Leucobryaceae, Bartramiaceae and Neckeraceae). The indicator species exclusive of this belt are Fissidens weirii, Pleurochaete squarrosa, Syntrichia lacerifolia and Leptodontium viticulosoides.

High Andean forest (2,000 2,400 m a.s.l.): The coverage of mosses in this area is equal to $22 \%$ of the total sample. The epiphytic mosses have a greater coverage at this point and this also seems to explain the increase in the diversity of this point with respect to the Low montane forest. The diversity of bryophytes also increases with 11 families (Pottiaceae, Bartramiaceae, Leskeaceae, Entodontaceae, Fissidentaceae, Macromitriaceae, Thuidiaceae, Hypnaceae, Brachytheciaceae, Meteoriaceae and Cryphaeaceae). The exclusive species exclusive of this belt are Erythrodontium longisetum, Chryso-hypnum elegantulum, Brachymenium klotzchii, Brachythecium rutabulum and Groutiella chimborazensis.

Montane-low forest (1,200 1,800 m a.s.1.): The coverage of mosses in this place represents only $9 \%$ of total sampling. The epiphytic mosses represent a higher percentage of the total than those on soil in this area, and include rare species such as Erpodium beccarii, widely known for characterizing alternative algae forests (Churchill \& Linares 1995) and which is a new record for Colombia. Fabronia ciliaris and Fissidens bryoides are new records for Boyacá. The diversity of mosses in this belt is low with only eight families of mosses recognized: Pottiaceae, Fabroniaceae, Erpodiaceae, Fissidentaceae, Bartramiaceae, Leucobryaceae, Brachytheciaceae and Sematophyllaceae. The indicator species exclusive of this belt are Pseudocrossidium replicatum, Fabronia ciliaris and Erpodium beccarii.

\section{Discussion}

The western region of the Sierra Nevada del Cocuy has a wide variety of ecosystems and climatic conditions that specifically influence the composition of moss populations. Our data show a marked difference between species composition of moss populations in all altitudinal belts and a varied preference in terms of available substrates. The diversity and coverage of mosses in this region increases with altitude, related to the decrease in temperature, the increase in humidity (Sporn et al. 2009, Stehn et al. 2010, Karger et al. 2012), and the high dominance of a few species at the lowest altitudinal points.

The change of species is very marked in all the altitudinal belts of this region although some species have very large distribution ranges such as Bryum andicola, which is present in all high mountain areas. Other species show a specificity for a particular environment and conditions, such as Fabronia ciliaris and Erpodium beccarii to the hot and arid climates in the low montane forest or Andreaea rupestris and Dicranum frigidum to climates of extreme cold and high humidity in the superpáramo. These distribution patterns are related to the adaptability of the mosses to a specific niche (Glime \& Vitt 1986, Slack 1998, Pullian 2000). The behavior of mosses differs in terms of the climatic conditions of the sector and the availability of resources.

The five established forest types have resources and environmental conditions that allow the specific assembly of the moss species in the altitudinal gradient: the superpáramo has a great availability of rocks due to its steep slopes, the forests have the highest and most abundant vegetation, and the páramos have more humid soils, rich in organic matter. This explains the great population differences and the way mosses adapt to each specific ecosystem (Hylander 2005, Spitale 2016, Spitale 2017). In this study the epiphytic mosses stand out for having a high sensitivity and a greater number of specific species confined to this substrate. This may be due to greater exposure to climatic conditions (Sales et al. 2016, Chen et al. 2017) and to the great variety of sampled phorophytes given by the change in the structure of the forest.

As in most zoning studies with bryophytes, the zones with the greatest diversity are found in the highest altitudes (Frahm \& Gradstein 1991, Kessler 2000, Sun et al. 2013). Our study shows that this is related to the type of forest and the increase in humidity and luminosity and the decrease in temperature. Places that did not meet these specific conditions lacked diversity and coverage. The mosses of dry ecosystems are totally different populations from those of montane climates. The latter have morphological adaptations so that their populations can survive in environments lacking water and humidity (Stark et al. 2009, Smith \& Stark 2014). The type of substrate does not seem to be mediated by environmental variables, but this may be related to the type of forest and the resources provided by it (Stehn et al. 2010, Spitale 2016, Spitale 2017).

\section{Acknowledgments}

We are very grateful to the Dr. William Buck, for critically reviewing the manuscript. The first author thank the Universidad Distrital Francisco José de Caldas, our Alma Mater, for educating us and showing us once again that the public university complies with the highest standards of international education.

\section{Literature cited}

Ah-Peng, C., Flores, O., Wilding, N., Bardat, J., Marline, L., Hedderson, T.A.J. \& Strasberg, D. 2014. Functional richness of subalpine bryophyte communities in an oceanic island (La Réunion). Arctic, Antarctic and Alpine Research 46: 841851. 
Albesiano, S. \& Rangel, J.O. 2006, Structure of the plant communities from Chicamocha canyon, 500-1200 m a.s.l.; Santander, Colombia : a tool for conservation. Caldasia 28: 307325.

Allen, B. 2002. Moss flora of Central America. Part 2. Encalyptaceae Orthotrichaceae. Monographs in Systematic Botany of the Missouri Botanical Garden 90: 1699

Bernal, R., Gradstein, S.R. \& Celis, M. (eds.). 2015. Catálogo de plantas y líquenes de Colombia. Bogotá, D.C.: Instituto de Ciencias Naturales, Universidad Nacional de Colombia. Available in http:// catalogoplantasdecolombia.unal.edu.co (access in 10 mar 2020)

Brunn, H.H., Moen, J., Virtanen, R., Grytnes, J.A. \& Oksanen, L. 2006. Effects of altitude and topography on species richness of vascular plants. Bryophytes and lichens in alpine communities. Journal of Vegetation Science 17: 3446.

Calabrese, G.M. 2006. A taxonomic revision of Zygodon (Orthotrichaceae) in southern South America. The Bryologist 109: 453509.

Cárdenas, A.S. 1995. Las Pottiaceae (Musci) del Valle de México, México. Acta Botánica Mexicana 33: 5161.

Chen, Y., Niu, S., Li, P., Jia, H., Wang, H., Ye, Y. \& Yuan, Z. 2017. Stand structure and substrate diversity as two major drivers for bryophyte distribution in a temperate montane ecosystem. Frontiers in Plant Science 8: 874. http://doi.org/10.3389/fpls.2017.00874

Churchill, S.P., \& Linares, E.L. 1995. Prodromus Bryologiae Novo-Granatensis. Introducción a la flora de musgos de Colombia. Bogotá, D.C.: Biblioteca José Jerónimo Triana. Tomos I y II. Instituto de Ciencias Naturales. Facultad de Ciencias. Universidad Nacional de Colombia.

Cleef, A.M. 1978. Characteristics of neotropical paramo vegetation and its subantarctic relations. Erdwissenschaftliche Forschung 11: 356390.

Clymo, R.S. 1987. The ecology of peatlands. Science Progress 71: 593614.

Cornelissen, J.H.C., Lang, S.I., Soudzilovskaia, N.A. \& During, H.J. 2007. Comparative cryptogam ecology: a review of bryophyte and lichen traits that drive biogeochemistry. Annals of Botany 99: 987 1001. https:// doi.org/10.1093/aob/mcm030

Cuatrecasas, J. 1934. Observaciones geobotánicas en Colombia. Trabajos del Museo Nacional de Ciencias Naturals. Serie Botánica 27: 1-44.

Cuatrecasas, J. 1958. Aspectos de la vegetación natural de Colomba. Revista de la Academia Colombiana de Ciencias Exactas 10(40): 221-268.

Cuatrecasas, J. 1968. Páramo vegetation and its life forms. In: Troll, C. (ed.). Geoecology of the Mountaineous Regions of the Tropical Americas. Colloquium Geographicum 9: 163-183.
Duarte, B. 1997. Musgos de Cuba. Madrid: Cyanus S.L. , $717 \mathrm{p}$.

Frahm, J.-P. 1990. The altitudinal zonation of bryophytes on Mt. Kinabalu. Nova Hedwigia 51: 133149.

Frahm, J.-P. 1991. Dicranaceae: Campylopodioideae, Paraleucobryoideae. Flora Neotropica Monograph 54: 1237.

Frahm, J.-P. \& Gradstein, S.R. 1991. An altitudinal zonation of tropical rain forests using bryophytes. Journal of Biogeography 18: 669678.

Frego, K.A. \& Carleton, T.J. 1995. Microsite conditions and spatial pattern in a boreal bryophyte community. Canadian Journal of Botany 73: 544551.

Gerson, U. 1982. Bryophytes and invertebrates. In: Smith, A.J.E. (ed.), Bryophyte Ecology. New York, Chapman \& Hall, pp. 291332.

Glime, J.M. \& Vitt, D.H. 1986. A comparison of bryophyte species diversity and niche structure of montane streams and stream banks. Canadian Journal of Botany 65: 1824 1837.

Glime, J.M. 1994. Bryophytes as homes for stream insects. Hikobia 11: 483497.

Glime, J.M. 2001.The role of bryophytes in temperate ecosystems. Hikobia 13: 267289

Glime, J.M. 2017. Temperature: Effects. Chapt. 101. In: Glime, J.M. Bryophyte Ecology. Volume 1. Physiological Ecology 10-1-1 Ebook sponsored by Michigan Technological University and the International Association of Bryologists. Available in http:// digitalcommons.mtu.edu/bryophyte-ecology2/ (access in 10 mar 2020).

Gobernación de Boyacá. 2018. Prensa y Publicaciones/ Aspectos geográficos. Available in http://www.boyaca. gov.co/prensa-publicaciones/mi-boyac\% $\% 3 \% \mathrm{~A} 1 /$ aspectos-geograficos (access in 10 mar 2020)

Gradstein, S. R. \& Frahm, J.-P. 1987. Die floristische Höhengliederung der Moose entland des BRYOTROPTransektes in NO-Peru. Beih. Nova Hedwigia 88: 105 113.

Gradstein, S. Robbert, Uribe-M, Jaime, Gil-N, Jorge Enrique, Morales, Claudia, \& Negritto, Maria A. 2018. Liverworts new to Colombia. Caldasia 40: 82 90. https://dx.doi.org/10.15446/caldasia.v40n1.68077

Gradstein, S., Churchill, S. \& Salazar-Allen, N. 2001. Guide to the bryophytes of tropical America. Memoirs of The New York Botanical Garden 86: 1577.

Graham, C.H., Carnaval, A.C., Cadena, C.D., Zamudio, K.R., Roberts, T.E., Parra, J.L., McCain, C.M., Bowie, C.K., Moritz, C., Baines, S.B., Schneider, C.J., VanDerWal, J., Rahbek, C., Kozak, K.H. \& Schneider, C.J. 2014. The origin and maintenance of montane diversity: integrating evolutionary and ecological processes. Ecography 37: 711719.

Griffin, D. \& Morales, M. 1983. Keys to the genera of mosses from Costa Rica. Brenesia 21: 299323. 
Grubb, P.J. \& Whitmore, T.C. 1967. A comparison of montane and lowland forest in Ecuador III. The light reaching the ground vegetation. Journal of Ecology 55: 3357 .

Halpern, C.B., Dovciak, M., Urgenson, L.S. \& Evans, S.A. 2014. Substrates mediate responses of forest bryophytes to a gradient in overstory retention. Canadian Journal of Forest Research 44: 855866.

Hernández-Hernández, R., Borges, P. A.V., Gabriel, R., Rigal, F., Ah-Peng, C. \& González-Mancebo, J.M. 2017. Scaling $\alpha$ - and $\beta$-diversity: bryophytes along an elevational gradient on a subtropical oceanic Island $(\mathrm{La}$ Palma, Canary Islands). Journal of Vegetation Science 28: 12091219.

Hernández, C.J., Walschburger, B.T., Ortiz, Q.R., \& Hurtado, G.A. 1992. Origen y distribución de la biota suramericana y colombiana. In G. Halffter (ed.), $L a$ Diversidad Biológica de Iberoamérica. Acta Zoológica Mexicana (n.s.) (pp. 3 24). Volumen especial de 1992. CYTEDD, México D.F., Programa Iberoamericano de Ciencia y Tecnología para el Desarrollo

Hylander, K. 2005. Aspect modifies the magnitude of edge effects on bryophyte growth in boreal forests. Journal of Applied Ecology 42: 518525.

IGAC- Instituto Geográfico Agustín Codazzi. 2008. Atlas Básico de Colombia, Tomos I y II, Bogotá D.C., Imprenta Nacional de Colombia.

Iwatsuki, Z. 1960. The epiphytic bryophyte communities in Japan. Journal of the Hattori Botanical Laboratory 22: 159339.

Karger, D.N., Kluge, J., Abrahamczyk, S., Salazar, L., Homeier, J., Lehnert, M., Amoroso, V.B. \& Kessler, M. 2012. Bryophyte cover on trees as proxy for air humidity in the tropics. Ecological Indices 20: 277281.

Kessler, M. 2000. Altitudinal zonation of Andean cryptogam communities. Journal of Biogeography 27: 275282.

Korner, C. 2007. The use of 'altitude' in ecological research. Trends in Ecology \& Evolution 22: 569574.

Lee, T.D. \& Roi, G.H. 1979. Bryophyte and understory vascular plant beta diversity in relation to moisture and elevation gradients. Vegetatio 40: 29 38. https:// doi.org/10.1007/BF00052012

León, G., Zea, J. \& Eslava, J. 2000. Circulación general del trópico y la Zona de Confluencia Intertropical en Colombia. Meteorología Colombiana 1: 3138.

Luteyn, J.L. 1992. Paramo: Why study them? In: Balslev, H \& Luteyn, J.L. (eds.), Páramo: An Andean Ecosystem under Human Influence. Academic Press, p. 114.

Márialigeti, S., Németh, B., Tinya, F. \& Ódor, P. 2009. The effects of stand structure on ground-floor bryophyte assemblages in temperate mixed forests. Biodiversity \& Conservation 18: 22232241.
Martínez-Abaigar, J., Núñez-Olivera, E. \& SánchezDíaz, M. 1993. Effects of organic pollution on transplanted aquatic bryophytes. Journal of Bryology 17: 553566.

McCain, C.M. \& Grytnes, J.A. 2010. Elevational gradients in species richness. In: Encyclopedia of Life Sciences (ELS). John Wiley and Sons, Chichester, UK. http://doi. org/10.1002/9780470015902.a0022548.

Mills, S.E. \& Macdonald, S.E. 2005. Factors influencing bryophyte assemblage at different scales in the western Canadian boreal forest. The Bryologist 108: 86100.

Monte, G.M. 1977. Monograph of the genus Meteoriopsis (Bryopsida: Meteoriaceae). The Bryologist 80: 584 599

Munoz, J. 1999. A revision of Grimmia (Musci, Grimmiaceae) in the Americas. 1: Latin America. Annals of the Missouri Botanical Garden 86:118 191. https:// doi.org/10.2307/2666219

Proctor, M.C.F. 1990. The physiological basis of bryophyte production. Botanical Journal of the Linnean Society 104: 6177.

Proctor, M. 2000. Physiological ecology. pp. 225247. In: Shaw, A. \& Goffinet, B. (eds.), Bryophyte Biology. Cambridge: Cambridge University Press. https://doi. org/10.1017/CBO9781139171304.009

Proctor, M.C.F. \& Tuba, Z. 2002. Poikilohydry and homoiohydric: antithesis or spectrum of possibilities? New Phytologist 156: 327349.

Proctor, M.C.F., Oliver, M.J., Wood, A.J. \& Alpert, P. 2007. Desiccation tolerance in bryophytes: a review. The Bryologist 110: 595 621. https://doi. org/10.1639/00072745(2007)110[595:DIBAR]2.0.CO;2.

Pulliam, H.R. 2000. On the relationship between niche and distribution. Ecology Letters 3: 349361.

Raabe, S., Muller, J., Manthey, M., Durhammer, O., Teuber, U., Gottlein, A., Forster, B., Brandl, R. \& Bassler, C. 2010. Drivers of bryophyte diversity allow implications for forest management with a focus on climate change. Forest Ecology and Management 260: 19561964.

Rangel, O. 1995. La diversidad florística en el espacio andino de Colombia. p. 187 205. In: Churchill S., Balslev, H., Forero, H. \& Luteyn, J.L. (eds.), Biodiversity and conservation of Neotropical montane forests. New York: The New York Botanical Garden.

Sales, K., Kerr, L. \& Gardner, J. 2016. Factors influencing epiphytic moss and lichen distribution within Killarney National Park. Bioscience Horizons: The International Journal of Student Research 9: 1 January 2016. https:// doi.org/10.1093/biohorizons/hzw008

Santos, N.D. \& Costa, D.P. 2010. Altitudinal zonation of liverworts in the Atlantic forest, southeastern Brazil. The Bryologist 113: 631645. 
Searles, P.S., Flint, S.D. , Díaz, S.B., Rousseaux, M.C., Ballaré, C.L. \& Caldwell, M.M. 2002. Plant response to solar ultraviolet-B radiation in a southern South American Sphagnum peatland. Journal of Ecology 90: 704713.

Simijaca, D., Vargas-Rojas, L. \& Morales Puentes, M.E. 2014. Uso de organismos vegetales no vasculares como indicadores de contaminación atmosférica urbana (Tunja, Boyacá, Colombia). Acta Biologica Colombiana 9: 221 232.

Slack, N.G. 1988. The ecological importance of bryophytes. In: Nash, T.H. \& Wirth, V. (eds.), Lichens, bryophytes and air quality. Bibliotheca Lichenologica 30: 2353.

Smith, R.J. \& Stark, L.R. 2014. Habitat vs. dispersal constraints on bryophyte diversity in the Mojave Desert, USA. Journal of Arid Environment 102: 76 81. https:// doi.org/10.1016/j.jaridenv.2013.11.011

Socolar, J.B., Gilroy, J.J., Kunin, W.E. \& Edwards, D.P. 2016. How should beta-diversity inform biodiversity conservation? Trends Ecology and Evolution 31: 6780.

Soderström, L. 1988. Sequence of bryophytes and lichens in relation to substrate variables of decaying coniferous wood in northern Sweden. Nordic Journal of Botany 8: 8997.

Soderström, L. 1993. Substrate preference in some forest bryophytes: a quantitative study. Lindbergia 18: 98103.

Spitale, D. 2016. The interaction between elevational gradient and substratum reveals how bryophytes respond to the climate. Journal of Vegetation Science 27: 844853.

Spitale, D. 2017. Forest and substrate type drive bryophyte distribution in the Alps. Journal of Bryology 39: 128 140. https://doi.org/10.1080/03736687.2016.1274090

Sporn, S.G., Bos, M.M., Hoffstaetter-Muencheberg, M., Kessler, M. \& Gradstein, S.R. 2009. Microclimate determines community composition but not richness of epiphytic understory bryophytes of rainforest and cacao agroforests in Indonesia. Functional Plant Biology 36: 171179 .
Stark, L.R., McLetchie, D.N. \& Roberts, S.P. 2009. Gender differences and a new adult eukaryotic record for upper thermal tolerance in the desert moss Syntrichia caninervis. Journal of Thermal Biology 34: 131137.

Stehn, S.E., Webster, C.R., Glime, J.M. \& Jenkins, M.A. 2010. Elevational gradients of bryophyte diversity, life forms, and community assemblage in the southern Appalachian Mountains. Canadian Journal of Forest Research 40: 21642174.

Sun, S.-Q., Wu, Y.-H., Wang, G.-X., Zhou, J. \& Yu, D. 2013. Bryophyte species richness and composition along an altitudinal gradient in Gongga Mountain, China. PLoS ONE 8: e58131. https://doi.org/10.1371/journal. pone.0058131

Taylor, A. 1919. Mosses as formers of tufa and floating islands. The Bryologist 22: 3839.

Van der Hammen, T. \& Cleef, A. 1986. Development of the High Andean Páramo Flora and Vegetation. In: Vuilleumier, F. \& Monasterio, M. (eds). High Altitude Tropical Biogeography. Oxford University Press, New York, USA, pp. 153201.

Van Reenen, G.B.A. \& Gradstein, S.R. 1983. Studies on Colombian cryptogams XX. A transect analysis of the bryophyte vegetation along an altitudinal gradient on the Sierra Nevada de Santa Marta, Colombia. Acta Botanica Neerlandica 32: 163175.

Van Reenen, G.B.A. \& Gradstein, S.R. 1984. An in investigation of Bryophyte distribution and ecology along an altitudinal gradient in the Andes of Colombia. Journal of the Hattori Botanical Laboratory 56: 7984.

Wolf, J.H.D. 1993. Diversity patterns and biomass of epiphytic bryophytes and lichens along an altitudinal gradient in the Northern Andes. Annals of the Missouri Botanical Garden 80: 928960.

Zander, R. 1972. Revision of the genus Leptodontium (Musci) in the New World. The Bryologist 75: 213280. Legends. 